\title{
Urban metabolism and river systems: an historical perspective - Paris and the Seine, 1790-1970
}

\author{
S. Barles \\ Laboratoire Théorie des Mutations Urbaines, UMR CNRS AUS, Institut Français d'Urbanisme, Université de Paris 8, \\ Champs-sur-Marne, France
}

Received: 4 June 2007 - Published in Hydrol. Earth Syst. Sci. Discuss.: 22 June 2007

Revised: 9 October 2007 - Accepted: 18 October 2007 - Published: 15 November 2007

\begin{abstract}
The aim of this paper is to analyse metabolic interaction between Paris and the Seine during the industrial era, 1790-1970, a period marked by strong population growth, technological changes, and the absence of specific legislation on environmental issues. The viewpoint focuses on exchanges of waters and wastes between city and river, quantifying them and tracing their evolution in the light of the strategies implemented by the stakeholders in charge. The study combines industrial ecology, local history and the history of technology.

From 1790 to 1850 , waste matters, and especially excreta, were considered as raw materials, not refuse: they generated real profits. The removal of human excreta aimed not only at improving urban hygiene, but at producing the fertilizers needed in rural areas. Discharging them into the river was out of the question. But after the 1860s, several factors upset this exploitation, notably domestic water supply: night soil became more and more liquid, difficult to handle and to turn into fertilizer; once utilised, the water had to be removed from the house; at the same time, the sewerage system developed and had negative impacts on the river. Even so, Parisian engineers continued to process sewage using techniques that would not only ensure hygiene but also conciliate economic and agricultural interests: combined sewerage system and sewage farms. Both of these early periods are thus noteworthy for a relative limitation of the river's deterioration by urban wastes. Not until the 1920s, when domestic water supply had become the standard and excreta came to be considered as worthless waste, was the principle of valorisation abandoned. This led to important and long-lasting pollution of the Seine (despite the construction of a treatment plant), aggravating the industrial pollution that had been in evidence since the 1840 s.
\end{abstract}

Correspondence to: S. Barles

(sabine.barles@univ-paris8.fr)
Analysing the priorities that led to the adoption of one principle or another in matters of urban hygiene and techniques, with the causes and consequences of such changes, enables us to understand the complex relations between Paris and the Seine. From raw material to waste matter, from river to drain, the concept of quality in environment remains the underlying theme.

\section{Introduction}

The history of the Industrial Revolution and of its impact on environments is often summed up as an accelerating deterioration of the latter, due to the intensification and diversification of human activities. Anthropogenic pressures appear to have grown relentlessly from the late 18th century to the 1970s and even later. Rivers in particular, as natural receptacles for liquid wastes, suffered early and continuous degradation as a result of increases in urban population and industrial production. This was all the more so since no consideration was given to problems engendered by pollution, hygienist models being content to clean up cities to the detriment of "residual" spaces (Neri Serneri, 2001). Cities thus became parasite ecosystems (Odum, 1989), living at the expense inter alia - of river systems.

This being said, a more precise study of urban metabolism (Wolman, 1965; Kennedy et al., 2007), focusing on the long term (Tarr and Ayres, 1990; Tarr, 2002; Douglas et al., 2002), creates a different impression, especially if the quantification of the exchange of materials - which constitute the most tangible link between societies and nature, cities and rivers is accompanied by an analysis of the priorities that guided decision-makers in supplying the water and removing the urban wastes that generated these material flows. In other words, our main thesis is that the degradation of rivers was

Published by Copernicus Publications on behalf of the European Geosciences Union. 


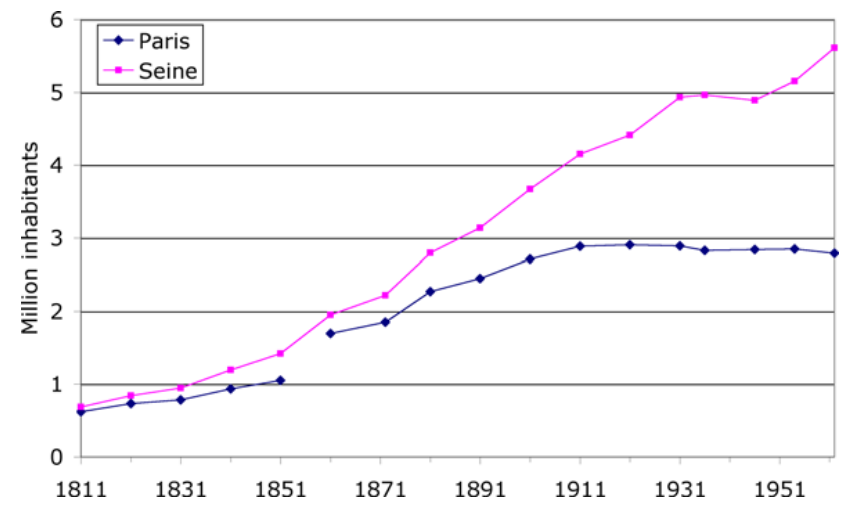

Fig. 1. Population, Paris (3402 ha, and 7802 ha from 1860 on), and Seine département (Paris and suburbs, 47280 ha), 1811-1962 (general censuses of the population).

not as continuous, systematic and deliberate as it appears at first sight. The aim of this study then is to investigate the case of Paris and the Seine, a thoroughly representative example of the issues at stake in an approach of this kind, Paris being the main built-up area of the Seine basin besides being the capital, and as such liable to adopt particularly stringent norms in matters of public health. The period of reference - 1790-1970 - covers both the first- and the secondphase Industrial Revolution, and ends at a time when the first environment-related laws were voted in France. What is at stake is to understand the interactions between Paris and the Seine, on the basis of the exchanges of matters, in the course of the industrial era, which was marked by sharp increases in population (Fig. 1), prior to systematic legislation on environment-related issues.

The study is based on a combination of methods derived from industrial ecology, in particular material balance sheets (Ayres and Simonis, 1994); urban history, which enables us to identify the major transformations of urban structures and the players involved in their different roles (see for instance Paris, 1990; Fierro, 1996); and the history of technology, by which we gain an understanding not only of the reasons behind the decisions made by people in charge but also of the functioning of one technique or another, and of repercussions in terms of quantities of matters (see for instance Billen et al., 1999; see also, more generally, Melosi, 1990). It draws on detailed and systematic empirical studies on water and nutrient flows in Paris (Barles, 2002a, 2007) and combines them with an analysis of changes in policy, technology and institutional settings concerning urban excreta (Barles, 2005a, b; Barles and Lestel, 2007). It proceeds by the exploration of public archives (in particular Paris Archives series VO3), of public statistics, and of the technical literature. The origin and quality of the quantitative sources is discussed in Barles (2007), the other sources are fully presented in Barles (2005a).
Section 1 depicts the situation in Paris before the generalized spread of water supply and sewers, that is to say from the 1790 s to the 1850 s, when urban wastes were considered as raw materials and not as refuse. After the 1860s (Sect. 2) a number of factors called into question traditional methods of dealing with urban wastes. Even so, Parisian engineers of the day chose to apply techniques for treating sewage that conciliated the exigencies of public health with economic and agricultural interests. Both of these early periods are thus marked by a limitation of the Seine's deterioration by urban wastes. Indeed, not until the 1920s (Sect. 3), when nightsoil came to be considered as worthless, and anthropogenic pressures had got out of hand, was the principle of recycling waste matters abandoned, thus generating widespread and lasting pollution of the river.

\section{1790s-1850s: the age of no waste}

\subsection{So little water}

At the end of the 18th century, water consumption in Paris remained low, and direct supply was limited to a few pipes that fed rich residences or monumental fountains. Distribution is estimated at $310^{6} \mathrm{~m}^{3} / \mathrm{yr}$ and $14 \mathrm{l} / \mathrm{cap} /$ day (Cebron de Lisle, 1991), and relied on the tapping of springs (Belleville, Pré-Saint-Gervais, Arcueil) and on machines that drew water from the Seine (Chaillot and Gros Caillou steam pumps, hydraulic machine at Notre-Dame bridge). Ordinary daily consumption was ensured by the gathering of rainwater, by direct drawing from the Seine, by the labour of water-carriers, and most of all by private wells, of which an inventory made in 1834 counted 22100 , about as many as there were houses (Guillerme, 2007). Overall consumption is not directly known, but it was nonetheless limited, even if there were a great many users: the urbanites of course (Fig. 1), but also their animals. In the years 1790-1800, there were oneand-a-half to two thousand cows and fifteen to twenty thousand horses stabled in Paris, not to mention far greater numbers of livestock in transit, whether for transport or butchery (Barles, 2007), all of which had to be watered.

However, scientists, doctors, engineers, architects and travellers had long denounced the filth of the capital - "in Paris, it is too far or too dirty wherever you are, because in Paris the mud defies description”, wrote Mozart in 1778 and insisted on the necessity of using powerful currents of water (and air) to clean it up and make it healthy. The canal de l'Ourcq (an affluent of the Marne), which was constructed from 1802 onwards, was designed to meet these ends. In this way a service was set up that was doubly public: first, because it was managed by the Parisian technical services that had been founded and kept up since the Premier Empire, second, because it was destined to the cleaning and enhancement of public space. London, where water supply was already in the hands of private companies and for the service of private 
owners, was considered to be a counter example by French engineers, who railed against the debasement of urban hygiene that resulted from this choice (Emmery, 1840).

When the Parisian water supply network came into service, in 1823 , the production capacity increased to $710^{6} \mathrm{~m}^{3} / \mathrm{yr}$ (Recherches, 1823) before jumping to $3210^{6} \mathrm{~m}^{3} / \mathrm{yr}$ in $1825,90 \%$ of which came from the Ourcq (Emmery, 1840). For the most part this network supplied the street fountains that served for cleaning public roads: they were turned on every day for one hour to carry away the rotting matter lying on the surface of the roadway and were not accessible to private interests. Added to these were the fountains for the use of city-dwellers and water-carriers alike, as well as several monumental fountains: in 1840, Paris had 16 monumental fountains, 84 public fountains, 1600 street fountains (of which 580 under construction or planned) (Emmery, 1840). Industries and trades drew their water directly from the city's water courses: the Bièvre, the Seine.

In spite of the development of this network, water remained rare (Fig. 2). However, it is to be noted that the share of rainwater, which still represented $90 \%$ of water inputs (rainwater and water for consumption) in the capital in 1807 , was outstripped by anthropogenic supply in the 1840s.

\subsection{The limited role of sewers}

In the early days then, water supply was not coupled with its collecting, so much so that in spite of its relative scarcity water was omnipresent in public space. Sewers covered barely $20 \mathrm{~km}$ at the close of the 18th century (Belgrand, 1887), and $40 \mathrm{~km}$ in 1831 (Emmery, 1834). Rainwater and anthropogenic water washed over the ground surface, and flowed in central gutters on streets, often stagnating, soaking away where the ground was still permeable, evaporating and generally contributing to urban humidity, or running off into the Seine intra muros. But the perfecting of less costly construction processes (the use of hydraulic lime, and later of cement), the outbreak of cholera in 1832, which caused 18402 deaths in Paris (Rapport, 1834), and the designing of streets with profiles better adapted to increases in traffic, soon led to the implementation of the first major programme for laying down sewers, which however, had only modest impact since the network covered only $168 \mathrm{~km}$ in 1858 (Bulletin, 1865).

Foremost, these sewers were designed to collect rainwater and the cleaning water from street fountains. Thanks to the new profile of streets - a cambered roadway bordered on each side by gutters that separated it from pavements (an early 19th c. innovation) - waters running off could now be channelled and evacuated underground once they had filled their cleansing function. All the skill of the engineers thus lays in choosing the optimal distance between fountain and access to drain. "Without a good system of drains, there can be no good system of water supply", insisted Darcy (1856).

The network did not collect domestic sewage: these wastes did not exist as waste but as raw materials and fertiliser (see

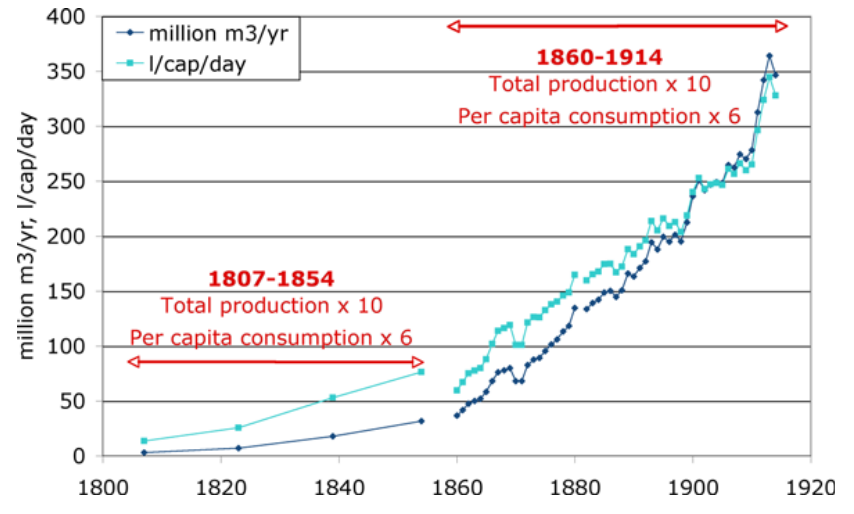

Fig. 2. Water production and consumption, Paris, 1807-1914 (adapted from Barles, 2002a).

next section), and did not exist as liquid waste (what is supposed to be sewage) as water consumption remained very low in households. Furthermore, up to 1852 the draining of houses was forbidden because it was considered to be unhygienic, and urban excreta were considered to be solid and useful.

\subsection{Urine and excrement: saleable commodities}

Given the techniques implemented in Paris to deal with urban wastes, the city's river system was little affected. Even so, the question of what to do with the excreta produced by the city was posed, since for the most part they did not end up in the sewage network. In this lies the main distinguishing characteristic of this first period: Paris (and to a lesser extent other French cities and some European ones) produced neither refuse nor wastewaters, but rather raw materials much in demand by both industry and agriculture. All the means implemented to improve the processing of excreta aimed at two objectives that were seen as inseparable and convergent: on one hand urban hygiene, on the other the optimum valorisation of urban by-products (Barles, 2005a, b).

City-dwellers were duty bound to keep their doorsteps clean by making midden heaps, which were scavenged by rag-pickers (a fast developing profession, whose profits came mainly from the sale of rags and bones) before being shovelled onto tipcarts by dustmen. The midden residue carted away represented roughly $1 \mathrm{l} / \mathrm{cap} / \mathrm{day}$, or $0.5 \mathrm{~kg} / \mathrm{cap} / \mathrm{day}$. It was deposited in specific dumps, where it remained for several years and was transformed into black sludge (as opposed to green, fresh sludge). This end product was then used by farmers in the vicinity of Paris. The agricultural use of sludge, so rich in organic matter, was an age-old practice, and farmers were bound by law to empty the dumps when they became saturated with decaying matter. But a major change came about in the 1770s: sludge, which had always been free, was now sold to farmers by cleaning contractors (Chassin, 1889). In spite of repeated complaints, by the end 


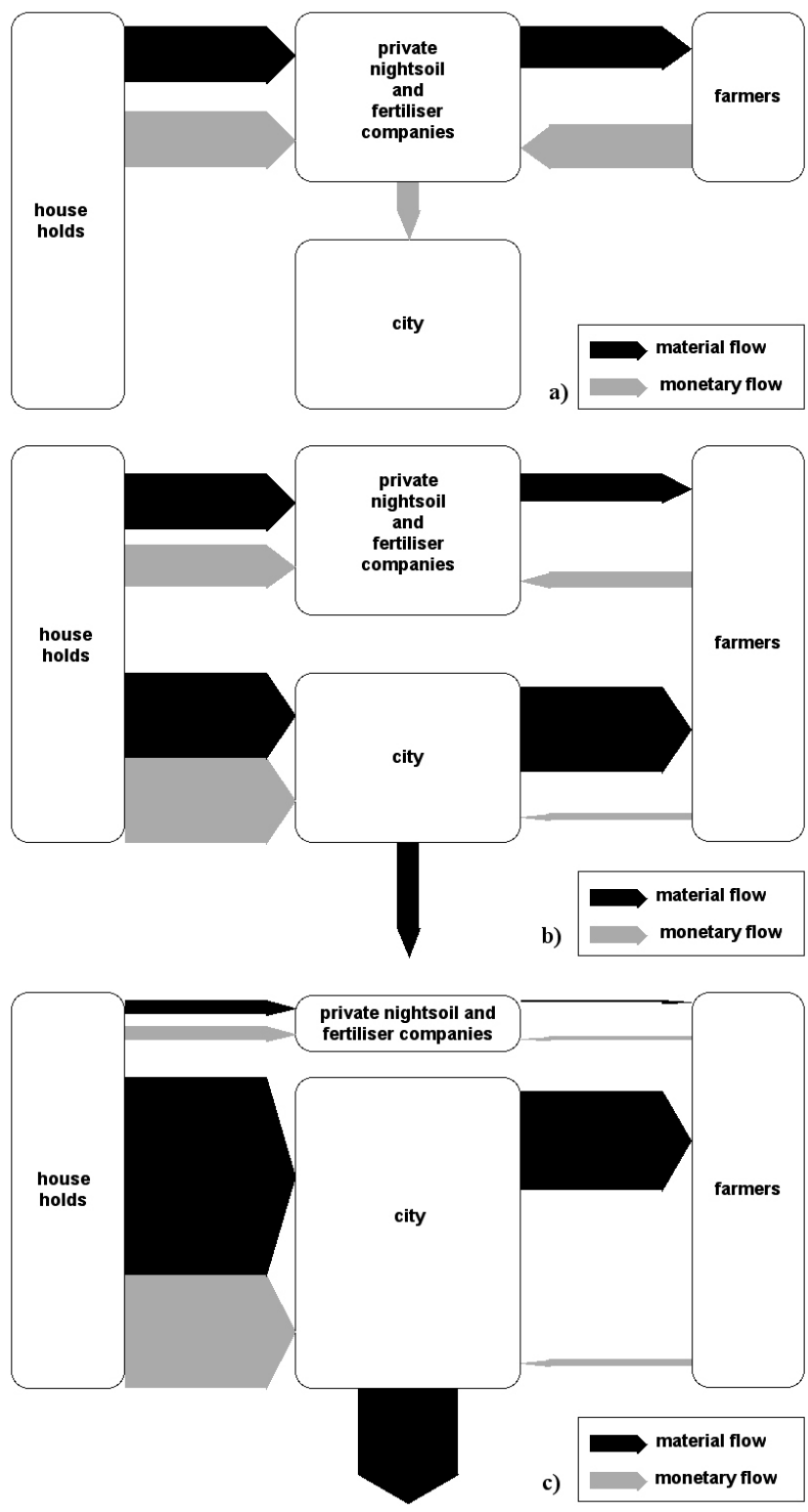

Fig. 3. Material and monetary flows for night soil and sewage, Paris. a) around 1860, b) around 1910, c) around 1935 . Arrows represent the direction of the flows and their thickness their importance (rough estimation, i.e. an arrow thicker than another just means a more important flow). Vertical arrows (to the river) represent voluntary pollutant discharge to the river (different from whole discharge). For more information see (Barles, 2005a).

of the 18th century the sale of sludge had become the rule. Similarly, cow dung, and horse manure even more, became the object of a lucrative trade, with rising prices. All of these matters, most of which were collected in the public space, were removed from the city, since "Agriculture has found a natural and inexhaustible source of fertility in the prodigious quantity of manure and ferruginous sludge supplied by the city" (Lachaise, 1822).
The use of human urine and excrement for making fertilizers was also a fast developing activity. These matters, which came from dry latrines, were collected in cesspools that were regularly emptied. The product of the emptying was transported to special depots, where as early as 1787 it was transformed into poudrette, a fertilizer patented in 1796 (Paulet, 1853 ) and "much in demand by ploughmen" (Thouret, undated). Bridet, the inventor of the poudrette de Montfaucon (from the name of a depot located on the north-eastern fringe of Paris), earned "enormous profits by the sale of its products in Normandy and the Brie and Orléans countries" (Belgrand, 1887). Urine and excrement were part of an economic circuit (Fig. 3a) that benefited the contractors that did the emptying, the keeper in charge of the depot (Bridet, and his successors), and the City of Paris, which rented the land for the depot at a steadily rising rate, bringing in "a revenue by no means negligible" (Paulet, 1853): 64000 French Francs (FF) per year from 1796 to $1805,166000 \mathrm{FF} / \mathrm{yr}$ from 1830 to 1842 , $380000 \mathrm{FF} / \mathrm{yr}$ from 1842 to $1850^{1}$.

Nonetheless, malfunctioning existed as of the 1810s. In spite of the low rate of water consumption, certain practices began to gain currency among the leisured classes of society, such as the bath at home. Now, "the bother of emptying the bathtub is of little concern to the sick or sensual man who has a bath carried up to his apartment" (Labarraque, Chevallier and Parent-Duchâtelet, 1835), who got rid of the water by way of the latrines. The few houses to benefit from supply by pipes did the same, so much so that the emptying of cesspools became more frequent not only because of population growth (Fig. 1), but also due to the fact that there was much more wastewater: $45000 \mathrm{~m}^{3} / \mathrm{yr}$ and $65 \mathrm{l} / \mathrm{cap} / \mathrm{yr}$ in $1815,90000 \mathrm{~m}^{3} / \mathrm{yr}$ and $117 \mathrm{l} / \mathrm{cap} / \mathrm{yr}$ in $1828,290000 \mathrm{~m}^{3} / \mathrm{yr}$ and 234 1/cap/yr in 1858 (Paulet, 1853; Belgrand, 1887; Annuaire, 1880). This liquefaction made the fabrication of dry and powdery poudrette more difficult, and the problem was clearly identified: "the obstacle faced by the administration at present stems from the mixing of solid matter with liquid matter" (Labarraque, Chevallier and Parent-Duchâtelet, 1835). Even so, the general principle was not questioned. In 1833 , when an anonymous citizen sent the Seine department's health council a memo arguing for mains drainage, his proposition met with a blunt rejection from the commission in charge of examining it, which "considers, that in the present state of affairs, the projects of M. Q... cannot be usefully applied in Paris; that they are not new; [...] and that his work can be of no use whatsoever to the administration" (Report, 1833). Two years later, a project for emptying liquid wastes into the Seine provoked the anger of cesspool contractors.

Improvements that followed were of two kinds. On one hand, there was a reorganization of installations: in 1818, the Montfaucon depot was doubled by that of Bondy located a few kilometres to the east of Paris, beside the canal de

\footnotetext{
${ }^{1}$ Paris Archives, VO3 450, see also Barles (2005a).
} 
l'Ourcq (just as in 1831, for reasons of hygiene, the sludge depots were moved further away); the closing of Montfaucon in 1848; the opening of private depots as of 1851; the transport of cesspool sewage by boat and later by pipeline for the liquid part, etc. (Mille, 1854). On the other hand, the companies in charge of sludge depots as well as the cesspool contractors developed a new fertilizer as a complement to poudrette, in order to exploit the liquid part. They had followed closely the work of chemists in France, who had attached increasing importance to the fertilizing role of nitrogen (Barles and Lestel, 2007) and who defended the principle of giving back to rural areas those "matters which cities owe to the earth" (Dumas, 1866).

As of the late 1820, the chemist Anselme Payen had attempted to concentrate the salts contained in cesspool sewage by evaporation of water, but the process was considered too costly. Distillation, which was experimented in laboratory by Jean-Baptiste Dumas in 1836, showed "that urines from Montfaucon contained enough ammoniac to keep going a factory for extracting this product" (Paulet, 1853). Industrial production of ammonium sulphate soon got under way, and by 1852 , the depot at Bondy alone was producing $10000 \mathrm{~m}^{3}$ of poudrette, 835 tons of ammonium sulphate, $8 \mathrm{t}$ of ammonium muriate, and $40 \mathrm{t}$ of volatile alkali (Beaudemoulin, 1853). While the poudrette was sold in a radius of 200 to $250 \mathrm{~km}$ around Paris, most of the ammonium sulphate was exported to England. Patents for the fabrication of the best fertilizers of human origin came thick and fast, and the stakes in play were considerable given the increased demand for foodstuffs: it was out of the question that these nutriments be thrown away into the river. This period is thus marked by an increase in the production output of urban fertilizers: analysis in retrospect shows that $20 \%$ of the dietary nitrogen (human and animal foods alike) that came into Paris in 1817 returned to agriculture in the form of sludge, manures and fertilizers of human origin, 24\% in 1869 (Table 1).

\section{1860s-1910s: liquid fertilization}

The valorisation of urban excreta reached its peak in the $1850 \mathrm{~s}$ and 60s. However, several factors were to compromise this circulation of matter between the city, industry and agriculture, which relied on exchanges and limited emissions of liquid waste.

\subsection{Domestic water supply and underground drains}

The point of view of the Parisian authorities as to the advisability of domestic water supply changed in the 1860s. Their doubly public service (see Sect. 2.1) had proved to be costly, all the more so since it generated no revenue at all, this at a time when the City of Paris, which had absorbed its outlying communes in 1860 , saw its area grow from 3400 ha to 7800 ha and its population from 1.25 to 1.67 million inhab- itants (Fig. 1). Apart from this, it had become abundantly clear that the fight for hygiene did not stop at the doorways of buildings, and the question of unhygienic dwellings was all the more pressing. Besides which, among the bourgeoisie there was a growing demand for comfort. Lastly, the incessant coming and going of water- and bath-carriers in streets and houses was increasingly considered to be a nuisance. All of these factors argued in favour of the development of domestic water supply, a project carried forward by Eugène Belgrand, the engineer in charge of waters and sewers in Paris.

Local production capacity soon proved to be insufficient: water would have to be sought elsewhere. Hence the tapping of distant springs that got under way in the 1860s (some of which over $100 \mathrm{~km}$ from Paris), the installation of new waterworks to exploit the Seine and the Marne, and the dual network that still benefits the capital today: the canal de l'Ourcq for bulk water used for cleaning streets and watering gardens; springs and rivers for other uses. Hence too the swift increase in domestic consumption, and the setting up of the Compagnie Générale des Eaux to sell water in Paris, the City's technical services retaining control of production, supply and infrastructures. Production capacity stepped up to $16410^{6} \mathrm{~m}^{3} / \mathrm{yr}$ in 1875 , and to $27010^{6} \mathrm{~m}^{3} / \mathrm{yr}$ by the end of the 19th century (Cebron de Lisle, 1991). By the eve of the First World War, the present-day structure of water supply was already in place and consumption had risen to between 300 and $350 \mathrm{l} / \mathrm{cap} /$ day (of which about a third was spring water, Fig. 2).

In parallel, a restructuring of the sewer network got under way. Belgrand's predecessors had designed it with an eye to limiting overall length: only half the streets were drained. But in 1852, when the disposal of domestic wastewaters (with the exception of those from latrines) via the sewer became compulsory, to limit direct spilling onto clean streets (Haussmann, 2000), the general draining of Paris became necessary. What is more, the network, which comprised a great number of outfalls to the Seine, was unified, and wastewaters were channelled downstream from Paris to limit contamination of the river and flood risks intra muros. The main sewer of Asnières, with its outfall in the Seine at Clichy, was built in 1858, while the Left Bank linked up with it after crossing under the river by means of a siphon (Fig. 4). By 1877,6500 hectares were serviced by the sewer network, which covered $570 \mathrm{~km}$ (Belgrand, 1887); and $1240 \mathrm{~km}$ in 1914 (Annuaire, 1914).

\subsection{The shortcomings of the traditional system}

These changes had considerable impact on the relations between the capital and her river. In effect, the role played by sewers had become more and more important as they shifted an increasing amount of water $-8610^{3} \mathrm{~m}^{3}$ in 1868 (Annuaire, 1880). This water was sullied by sand and mud due to the spread of macadamized roadways (made of broken 


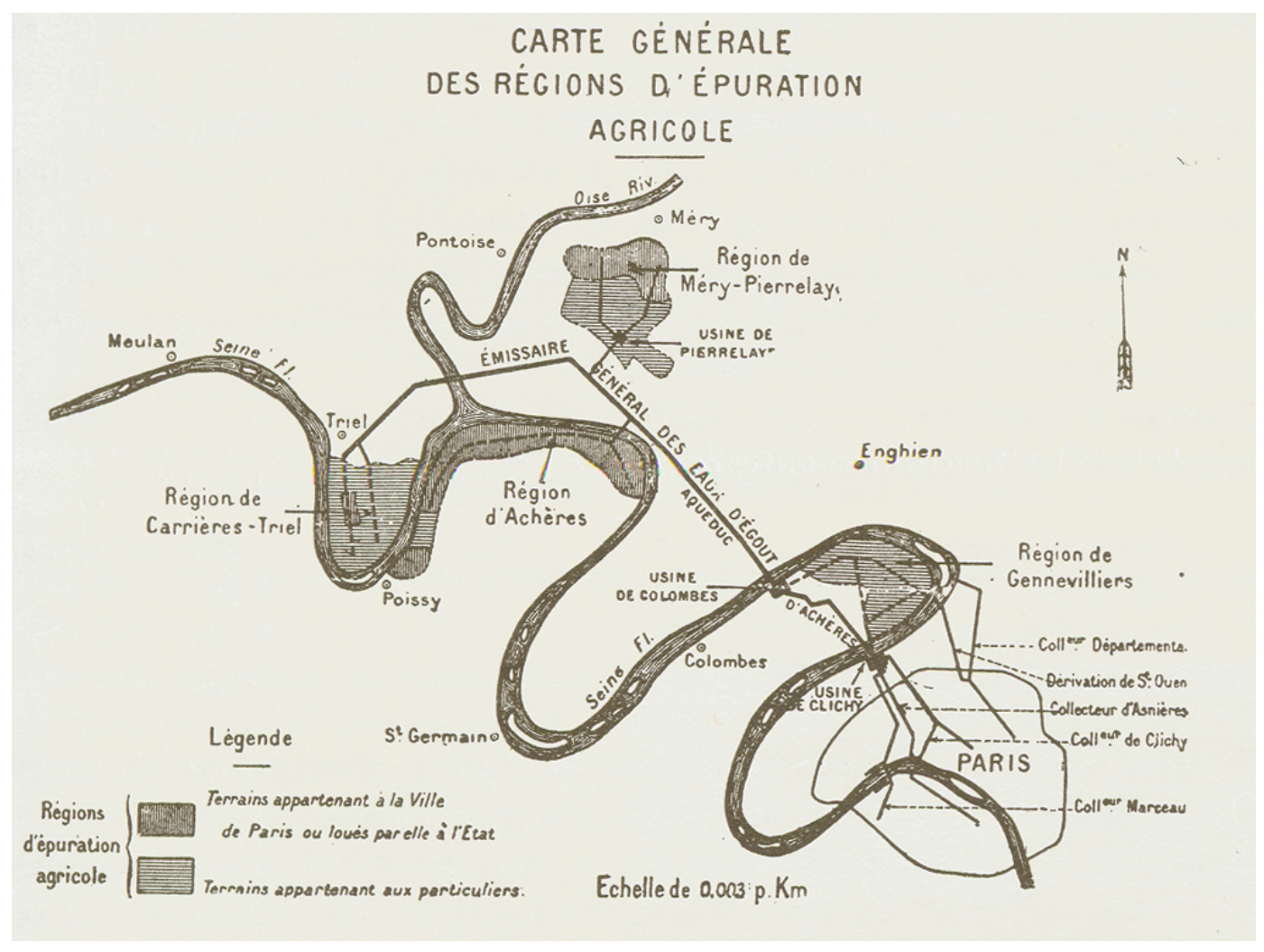

Fig. 4. Paris main sewer system and sewage farms at the beginning of the 20th century (Gérards, 1907).

stones) and the intensification of traffic that wore down their surface (macadamized streets totalled 1 million square metres in 1857,2 million in $1872^{2}$ ), by organic matters due to industrialization, by the presence of more horses (54300 in 1874, but more by far moving about in the streets), and by the adjunction of domestic wastewaters. The situation was all the more alarming in that contamination of the Seine by industrial activities had been signalled as of the late 1840s (Lestel, 2005). The coming into service of the Asnières main had as immediate effects the swift decline in the quality of water, the formation of shoals that endangered navigation, and the multiplication of cases of fever at Clichy, in short, the "pollution of the Seine" (Arnould, 1889).

Other problems faced those in charge of removing urban excreta, and in particular the emptying of cesspools. Liquefaction had intensified: the $1.110^{6} \mathrm{~m}^{3}$ of nightsoil removed from Parisian cesspools in 1880, equal to a production of $500 \mathrm{l} / \mathrm{cap} / \mathrm{yr}$ (Annuaire, 1880), was twice as much as in 1858. Excess waters from depots went to the sewer and added to the contamination of the river. In spite of improved processes for making fertilizers, production output remained low: "At Bondy, in 1869 , only $1 / 5$ of the nitrogen was used, $1 / 2$ returning to the Seine in the form of sluice-waters, and roughly $1 / 3$ being lost by evaporation and decomposition" (Gastinel,

\footnotetext{
${ }^{2}$ Archives of the Préfecture de Police, DA 30, document 140.
}

1894). As for poudrette, it was steadily losing favour among agronomists: its preparation was described as a "monstrous operation", "the ne plus ultra of waste" (Girardin and Du Breuil, 1885).

Apart from this, fertilizers of other origin had come in for competition. The discovery of fossil deposits of phosphates as of the 1850s showed that cities, with their cesspools and abundance of animal bones, no longer constituted the prime source of phosphorus. Sodium nitrate from Chile, which began to be imported in small quantities in the 1860 s, gradually increased its market share (Daujat, 1957). More generally, after the 1880 s, mineral fertilizers, which up till then had not been popular in France, found more and more advocates: "With chemical fertilizer we command cultivation, whereas with manure alone it is cultivation that commands us" (Dureau, 1886). Similar evolution is to be observed concerning sludge from streets and the products of scavenging.

Lastly, private depots had proliferated around Paris - there were as many as forty-five around 1880 (Jacquemet, 1979). They came in for stiff denunciation from locals because of their stench and lack of hygiene. Emptying operations too came in for the same criticism. In spite of the improvements made, they remained unhygienic. And they slowed down traffic, jamming the city's already congested streets.

These difficulties affected both the makers of urban fertilizers, since production costs were on the rise while selling 
prices fell, and the administration, which had to ensure public hygiene but made less and less profit from urban excreta. As of the 1860s the reform of cesspool emptying was on the agenda. Even so, the valorisation of wastes remained primordial.

\subsection{Main drain and agricultural spreading}

The problems posed by disposal into the Seine and those of the traditional methods of emptying cesspools led Parisian engineers to look at urban hygiene from a different angle. As early as the 1860s, two of them, Adolphe-Auguste Mille and Alfred Durand-Claye, became convinced of the necessity of mains drainage, that is to say of the evacuation via the sewers of toilet waters as well as domestic wastewater. But they were just as convinced of the value of urban excreta and of the necessity of their agricultural use. To them, the mains drainage project could not be complete unless it were accompanied by the spreading of wastewaters in sewage farms, a technique that had already been tested in Europe for some thirty years (Mille and Durand-Claye, 1869). The combination of mains drainage and agricultural irrigation would enable them to ensure urban hygiene by doing away with the transport of barrels to empty cesspools, encourage the linking up of dwellings to water supply, thus facilitating interior hygiene, and limit the contamination of the Seine and hazards to navigation - all this while supporting agricultural production and, last but not least, gaining some revenue from excreta in liquid form, the fertilizing value of which was estimated at $0.125 \mathrm{FF} / \mathrm{m}^{3}$, given its content in nitrogen, phosphorus and potassium (Freycinet, 1870).

The ultimate goal of cleaning up the city was clearly stated, and was summed up by the engineer Charles de Freycinet: it was a matter of ensuring continuous circulation of water and the matter that it carried, and this in three phases - the supply of pure water, underground piping or drainage, purification. Indeed: "The third phase of continuous circulation, is $[\ldots]$ the purification of sewage, that is to say the putting back into the earth of the main fertilizing components that it contains, and the returning to rivers of liquids free of their corrupting elements. Today, no one questions the need for this purification. Two imperious reasons support it: hygiene and agricultural importance" (Freycinet, 1870).

The first experiments began in the late 1860s and Belgrand rallied to this solution in 1870 , soon to be followed by the Parisian administration. Even so, the project had many opponents, among whom were doctors, fertilizer-makers, owners of buildings, and communes concerned by sewage farms (Jacquemet, 1979). Its implementation was delayed, connection of dwellings to the sewage network was optional after 1885 , compulsory in 1897 ; the percentage of buildings connected went from 32\% in 1900 to $68 \%$ in 1914 (Annuaire, 1900, 1914); while sewage farming sites multiplied downriver from Paris (Gennevilliers was first, then in 1895 Achères, then Carrières-Triel and Méry-Pierrelaye in 1898,

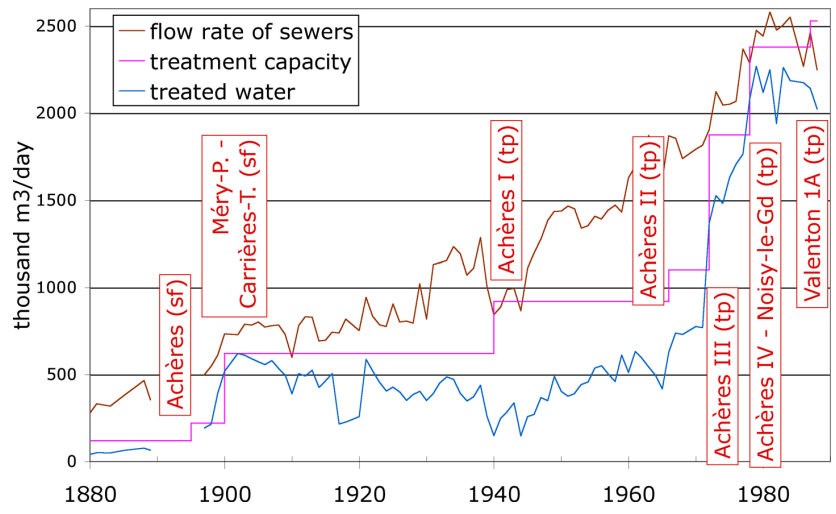

Fig. 5. Flow rate of sewers, treatment capacity, treated water, Paris conurbation, 1880-1988. In red: main treatment facilities. sf: sewage farm, tp: treatment plant (Barles, 2005a).

Fig. 4); they peaked at 5100 ha early in the 20th century, with a legal proportion of irrigation of $40000 \mathrm{~m}^{3} / \mathrm{ha} / \mathrm{yr}$, six times the rainfall of Paris (Vincey, 1910).

The urban hydrological cycle was thus profoundly modified: sewers gradually enabled the collection of the majority of rainwater and supply water to the detriment of infiltration (all the more so as tar-sealed roads became more common) and evapotranspiration. The latter phase of the hydrological cycle was shifted as it were to the sewage farms. Furthermore, the excellent agricultural and economic advantages of the method became clear. "The quantity of produce is always considerable, at times prodigious. The same ground easily yields two harvests, the same meadow four or five crops of hay in our climates." The "excellence" of the quality of products "is attested not only by the ease with which they are sold on markets and by the prices they command, but even more so by results obtained in competitions and fairs." (Bechmann, 1899). Production was abundant. Considering fodder beet alone, the yields gazetted for the 1880s was impressive: $1050 \mathrm{q} / \mathrm{ha}$, while in 1885 the yield for the entire Seine department - the best in France - was 619 q/ha, 248 q/ha for all of France (Statistique, 1886). Although the areas in question were hardly comparable, they help us to understand the tone of general enchantment... "The entire population owes its well-being to this thorough metamorphosis." (Baudrillart, 1888)

During a short period - up to World War I -, the treatment capacity bordered on that of the flow rate of Parisian sewers (Fig. 5) and both engineers and agronomists could delight in the effectiveness of sewage farming. Analysis in retrospect shows that $40 \%$ of the dietary nitrogen (human and animal foods alike) that came into Paris in 1913 returned to agriculture, twice the figure for a century before. The sewage farms accounted for almost one half of this transfer of nutriments (Table 1). For the year 1906, a more precise balance sheet of the effect of spreading has been drawn up on the basis of data given by the agronomist Paul Vincey (1910). In 
Table 1. Main characteristics of dietary Nitrogen balance, Paris, 1817, 1869, 1913, 1931 (Barles, 2007).

\begin{tabular}{lrrrr}
\hline & 1817 & 1869 & 1913 & 1931 \\
\hline Human population & 716000 & 1840000 & 2893000 & 2885000 \\
Horses population & 16500 & 50000 & 55000 & 10000 \\
Food inflows (tN) & 6100 & 17600 & 23500 & 19700 \\
Urban fertiliser produced & & & & \\
Street sludge (tN) & 500 & 1300 & 2100 & 700 \\
Horse manure (tN) & 600 & 1800 & 1800 & 400 \\
Human manure (tN) & 100 & 1100 & 1200 & 100 \\
Wastewater to sewage farms (tN) & 0 & \pm 0 & $4000^{*}$ & $4000^{*}$ \\
Total outflows to agriculture (tN) & 1200 & 4200 & 9100 & 5200 \\
$\%$ of food inflows & 20 & 24 & 40 & 26 \\
Direct discharge to Seine (tN) & $?$ & $?$ & 3100 & 7000 \\
$\%$ of food inflows & $?$ & $?$ & 13 & 36 \\
\hline
\end{tabular}

* This concerns only the dietary Nitrogen. The total amount of Nitrogen in wastewaters is more important.

that year Parisian sewers transported 7100 tons of nitrogen; of which $5200 \mathrm{tN}$ went to agricultural irrigation (73\%), and $1900 \mathrm{tN}$ went straight back to the Seine. The nitrogen of the sewage farms was partially recuperated in drains, and a further $2300 \mathrm{tN}$ went back to the Seine in this way. All told the river got $4200 \mathrm{tN}$ (60\% of the total from the sewers). Finally, the fields "retained" $2900 \mathrm{tN}$, or $40 \%$ of the total, part of which was consumed by plant growth. The role of spreading was thus threefold: first, it ensured that a by no means negligible share of the nitrogen transported by the sewers did not go into the river; second, it enabled emissions into the river to be spread out over a considerable distance (the effect on the quality of water of the $4200 \mathrm{tN}$ finally rejected would probably have been very different had it depended on the sewer discharges at Clichy and Saint-Denis alone, which are very near to one another); third, the nitrogen discharged at Clichy and Saint-Denis was mainly in ammoniacal form, whereas the sewers transported nitrates for the most part, so again, the impact on the quality of the aquatic environment was modified. These tentative results should be correlated with those of studies of chronicles concerning the river water quality (Cun and Vilagines, 1997) to enable precise analysis of environmental response.

This period nonetheless saw one significant change: whereas the City of Paris had hoped to reap considerable profits from sewage farming, or at least cover expenses, it had to admit that the solution was costly. True, produce was abundant, but it was the farmers who benefited from it even though they contributed little or nothing to irrigation costs, which proved to be very high. As early as 1900, revenue from the sewage farms and the sale of vegetables grown in model gardens at Gennevilliers and Achères amounted to barely $130421 \mathrm{FF}$, while running costs alone stood at $1875000 \mathrm{FF}$ (Martin, 1902). There was no denying the agricultural and sanitary importance of spreading, but it was no longer accompanied by economic interest (Fig. 3b).

\section{1920s-1970s: the birth of wastewaters}

Regardless of the good results of agricultural spreading, and in spite of the Parisian administration's avowed intent to continue valorising excreta, the post-WW I period saw a thorough calling into question of both these principles.

\subsection{The limits of sewage farming}

The sewage farms soon showed their limits. Apart from basic incompatibility between the seasonal demand for irrigation and the continuous production of sewage, there was insufficient available land, all the more so after World War I. Water consumption rose to $4001 /$ cap/day in 1924 , then oscillated between 400 and 5001/cap/day up to the 1960s (Fig. 6), in phase with population growth and the number of homes connected to the supply network. At the same time, more homes were connected to the sewer network - 88\% in 1931 (Annuaire, 1931). Needless to say, the flow rate of the sewers increased too, outstripping the treatment capacity (Fig. 5). The search for new sites for farming sewage became all the more difficult as urban development spread to territories further from the city centre.

As well, up until World War I, the City of Paris had been content to implement projects for water supply and drainage that ignored suburban areas, in spite of their rapid growth. There were 1.5 million suburbanites in $1921,2 \mathrm{M}$ in 1931 , as against $2.9 \mathrm{M}$ inhabitants for Paris intra muros, a figure that remained fairly constant between both dates (Fig. 1). Water consumption in the suburbs remained less than that intra muros (941/cap/day in 1900, 150 1/cap/day in 1921, $2001 /$ cap/day in 1933, Fig. 6), but the consequences for the Seine were not negligible: the quantity of river water drawn increased, as did the discharge of raw sewage. Added to this overall consumption was industrial demand, also very much on the increase. These problems had been signalled at the 
very start of the 20th century: "During the summer of 1900 in particular, pressing complaints were made concerning the persistent infection of the river" (Vincey, 1910). In 1905, the flow rate of Parisian sewers represented $78 \%$ of the total for the entire built-up area, but $72 \%$ of this wastewater was processed in the sewage farms, so much so that direct outfall from the suburbs was equal to that of Paris (Vincey, 1910).

In view of this, it became increasingly difficult to act as if the suburbs did not exist. As of 1911, the general council of the Seine department insisted on the need for a cleaning up programme, due to the exhaustion and deterioration of natural resources, a delicate matter after the drought of that same year, during which the Seine literally stopped flowing (Sentenac, 1928).

Yet it was not until the between-war period that these new conditions were taken into consideration. In the meantime, in the 1920s, the situation had grown worse: whereas the Seine's low-water flow rate was barely $35 \mathrm{~m}^{3} / \mathrm{s}$, water drawn from the river reached $28 \mathrm{~m}^{3} / \mathrm{s}$ (not counting the quantities drawn by power stations), so much so that the State was forced to refuse a demand by the City of Paris for an increase in the quantities drawn. Elsewhere, the quality of water deteriorated: increased consumption meant a corresponding increase in wastewaters, both urban and industrial, and given the river's sluggish flow rate due to this same increase, outfall sewage was not diluted. Simultaneously, wastewaters from power stations caused an alarming rise in water temperatures (Sentenac, 1928; Gilbert, 1958).

\subsection{Large-scale solutions}

The first remedial projects developed by Parisian authorities reflect continuity in the viewpoints of the city's engineers, for whom the natural resource was deemed unlimited and the needs of the capital the priority. Since there were no more springs to be tapped (the last diversion was done in 1926), water would have to be brought from further away, in another basin, hence projects in the 1920s and 30s for tapping water from Lake Geneva or the Loire valley (Sentenac, 1928; Koch, 1949). But at the same time, an age-old fear had resurfaced: the flood of 1910 had revealed the capital's vulnerability. The construction of reservoir-dams upriver, already envisaged fifty years earlier, appeared to be the solution for safeguarding the city. But the retention capacity required demanded enormous investments; so the project was re-oriented and the first dams that came into service in the 1930s were essentially designed to maintain a low-water level that would ensure both navigation and the drawing of water in summer, since supporting the minimum flow-rate demanded a retention capacity far less than that of controlling flood risk (Gilbert, 1958).

In parallel, the technical services of the City of Paris sought other sites for sewage farming, further away, where agricultural irrigation might come into its own and real estate pressure did not exist. In the 1920s, they developed plans to

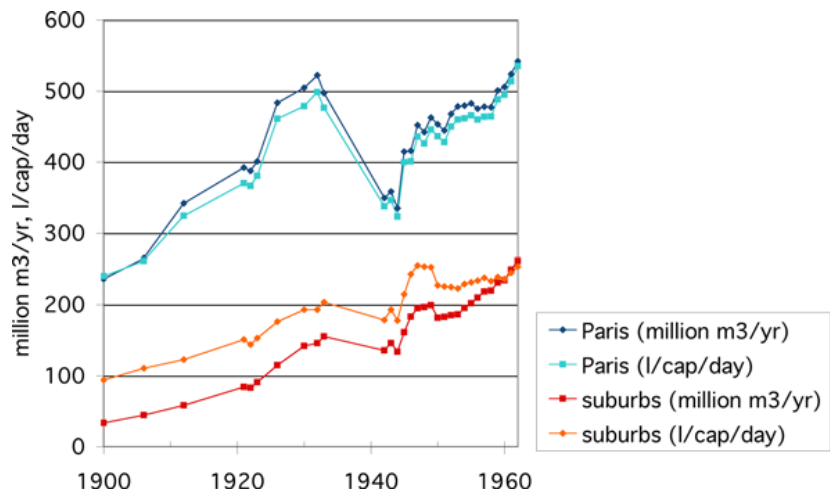

Fig. 6. Water production and consumption, Paris and suburbs (other municipalities of the Seine département), 1900-1962 (adapted from Barles, 2002b).

irrigate the dry Champagne region, which had been devastated by WW I trenches, so as to "re-stimulate agriculture on grounds ill-suited for farming, because the soil is too chalky, and thus too dry in summer due to cracking." (Védry, 1992) Bernard Védry reports that two variant projects were studied, both of them based on building an aqueduct $140 \mathrm{~km}$ long, one to the north of Reims, where laid 38000 ha of irrigable land, the other to the south of the Marne, which offered 28000 ha. The problem of removing and processing sewage would thus be solved once and for all, and once again to the benefit of agriculture.

But the sewers of Paris never irrigated the Champagne region. Costs were probably too high, while synthetic fertilizers became more competitive, all the more so given the difficulties encountered in exploiting the sewage farms already in operation and the fact that agronomic science had shown that sewage did not constitute as superior a fertilizer as it had once been thought to be, due to the inadequate proportions of its nutrients (Koch, 1937). The very objectives of purification changed, and became far narrowest: according to Pierre Koch, the Seine department's head of sewerage system (1937), the central issue was simply to disintegrate organic matter. There was a growing interest in the biological processes of purification, which enabled "the setting to work of the same microbial agents as those that accomplish natural purification, but in such a way as to produce the maximum amount of disintegration of organic matter within the smallest possible space and in the shortest lapse of time" (Courmont et al., 1932).

Accordingly, when the general sewerage system scheme for the Parisian built-up area was approved in 1929, a project designed to meet needs up to 1970 , the biological treatment of sewage was adopted (Olivesi, 1966). Based as it was on a network of main sewers laid out in fan array, the branches converging at Achères, it used the same principle as the Parisian network, but on a larger scale, and introduced the principle of treatment by means of activated sludge. The 
Achères I wastewater treatment plant, which came into service in 1942 , had a purification capacity of $200000 \mathrm{~m}^{3} /$ day. Subsequent extensions made it for a long time the world's largest treatment plant after that of Chicago.

But as of the plant's inception, sludge posed a problem. Even if, as of 1944, fermentation produced methane gas, which, once compressed, could be used to run government vehicles (Koch, 1949), this outlet lost its interest at the end of the war. At the same time, the experimental station at Colombes, with a capacity of $6000 \mathrm{~m}^{3} /$ day, enabled "experimenting modern processes of sewage treatment and the carrying out of research into the recuperation of sub-products derived from sewage." (Koch, 1949). A test-bed garden of $15000 \mathrm{~m}^{2}$ was laid out in an attempt to recycle gas, but to no avail: sludge remained a headache (Olivesi, 1973).

Sewage farming was not abandoned though, even if the farmed areas shrank year by year. 4500 hectares in 1949 , 4040 ha in 1966, 2000 ha in 1983 (Véron, 1983): it could not withstand urban and industrial pressure. But it was with regret that the technical services of Paris saw this activity diminish. In the 1950s and 60s there was still talk of "large yields", with "often two market garden crops a year", and it was remarked that sewage farming "contributes, to a considerable extent, to supplying the Parisian market and [that it] plays the role of a price regulator." Attention was drawn to its "particularly precious" contribution during the war (Koch, 1949; Feuillade, 1966). These commentaries, which appeared in special issues that the review Science et industrie (later re-named Travaux) did on Parisian technical services, were not re-published in the 1973 edition: alas, even if the technique was not truly abandoned until 1999 , it was already obsolete.

\subsection{The Seine: river or drain?}

In parallel to this, growing discrepancy became apparent between hygiene-related intentions and actual practice. Koch (1937) had indeed insisted on the dual necessity of protecting both inhabitants and natural environment, when he entitled the second volume of his course: The protection of natural environments and the treatment of urban effluents and when he wrote: "as for the purification of residual waters, we need only look at the state of large or medium-sized rivers downstream, or even in their crossing of built-up areas which do not take sufficient care of them, to be persuaded of its usefulness."

The texts of State regulations, however, were less affirmative. In its Instructions relatives à l'assainissement de villes in 1933, the Conseil supérieur d'hygiène publique of France asserted that it "could only give its approval to plans that shifted rapidly away from the built-up area all wastewaters, including faeces, eradicating them and moving them to a place where they can not cause harm to anyone." The Instruction technique relative à l'assainissement des agglomérations of 1949 (commonly known as the "Caquot cir- cular"), mentioned "minimum processing, to be carried out even in the most favourable circumstances" (Ministère de la Reconstruction et de l'Urbanisme, 1949), but in the final analysis imposed nothing. Technical instructions published the following year (12 May 1950) clearly stated the sanitary objective, but did not enforce any "obligation of total or partial purification of sewage waters, of which it is, however, simply recommended that the best final destination be sought, whether it be discharge in the sea, in a lake, a pond, a water course or on the ground." (Loriferne, 1987) The law on water of $1964^{3}$ introduced the notion of compatibility between wastes and the uses of water, but it was not until 10 June 1976, with the circular of the ministry of Health pertaining to the cleaning up of built-up areas and the protection of the natural environment that the latter was taken into account.

The period 1930-1970 is thus marked by the constant "behind schedule" state of purification measures. Human excreta, having lost all economic and agricultural value, no longer represented a subject of sufficient importance to justify a strong-willed policy. Even the hygienist concerns that attended the subject were probably toned down: the perfecting of processes for ensuring the quality of drinking water and their generalization diverted attention from the poor quality of the resource. Environmental awareness, which we see in Koch, was not yet sufficiently widespread to support the sewage treatment. In this way, the treatment capacity in the Parisian built-up area was for a very long time inferior to needs (Fig. 5), and the Seine saw its quality continue to decline. In 1931, it is likely that $36 \%$ of the dietary nitrogen in Paris was evacuated directly into the Seine, a percentage three times that of 1913 (Table 1), to which must also be added the other sources of nitrogen, both in Paris and her suburbs. The low rate of purification at Achères along with the increase in volumes to be processed only served to worsen the state of the river. This urban pollution added to the industrial one - a known but not quantified problem at that time.

Human excreta, which had once contributed to the wealth of Paris, were henceforth a liability: "The processing of effluents constitutes a charge that built-up areas naturally tend to consider as frustrating, since they make no direct profit from it." (Koch, 1937). At the best, wastes were treated, at the worst, they were abandoned (Fig. 3c). The useless character of sewage paved the way for the invention of a new expression, eaux usées (wastewaters), which was coined by the engineer Georges Bechmann in 1899 and gained currency in the 1930s, at the same time as the expressions déchets ménagers (household wastes) and déchets urbains (urban wastes) for solid excreta (Barles, 2005a).

\footnotetext{
${ }^{3}$ Law $64-1245$ of 16 December 1964 pertaining to the status of waters, their sharing and the fight against their pollution.
} 


\section{Conclusions}

"The diverse Waters that people drink in Paris are very pure, $\&$ as such most fit to furnish a healthy drink. [...] Among these waters, that of the river Seine is the purest and lightest of all" (Parmentier, 1787). This quality - which of course begs closer scrutiny - has not survived industrialization and urban sprawl. Even so, up to the 1920s, the people in charge of removing urban and human sewage were not content to simply evacuate it via the river. As in other cities (see for instance: Tarr, 1975; Hamlin, 1980; Goddard, 1996; Mårald, 2002), excreta represented a source of manure and exploitation of this resource was considered vital to the survival of populations. Its processing brought important profits to the many stakeholders involved in its handling: cesspool contractors, fertilizer-makers, City of Paris, farmers, etc. But even when the traditional processes of cesspool management began to be called into question, notably by generalized domestic water supply as of the 1860 s, the Parisian authorities continued to favour techniques of sewage disposal that benefited agriculture. Their engineers advocated the use of sewage for irrigation, which seemed to be the appropriate response to the many issues raised by the removal of human excreta: hygiene for Paris and for people living near the Seine, safeguard of river traffic, profits for the municipality, agricultural production... This point of view was not isolated, and the advantages of sewage farms were discussed in Europe and America at the same time (see for instance Melosi, 2000), but it seems that French engineers and chemists remained convinced of their superiority - as they remained convinced of the usefulness of garbage - longer than their counterparts in other countries - a fact that requires further investigation and reveals the need for comparative studies.

In spite of encouraging results in terms of marketable crop yields, sewage farming proved to be too costly, besides demanding extensive surface areas; it could not compete with the spread of Parisian suburbs or with the revolution in fossil and chemical fertilizers. By the early 20th century, wastes produced in suburban areas also became a source of concern; in the 1920s, the state of the Seine led to the elaboration of a new disposal protocol, which although it did not abandon sewage farming outright, was essentially based on biological treatment of wastewater in processing plants. But as of the moment when the role of public hygiene was reduced to disposal, since this activity generated costs for the administration and no profits, the projects implemented for the purification of what had come to be known as wastewaters were constantly behind schedule. This discrepancy, coupled with the expansion of the Parisian built-up area, led to long-term deterioration of the river by urban wastes. Not until the law of 1964 on water, with the setting up of monitoring stations in the basin and the application of the polluter-pays principle, did the situation begin to stabilize: in the 1970s, the treatment capacity drew level with the volumes to be processed.
Sewage from urban areas was not the only source of the Seine's pollution (the word gained currency in France in the 1870s), and we should not conclude from this study that the river remained largely free of contamination until the 20th century. Industrial wastes had an established impact on water quality as early as the 1840 s, and continued to increase during the entire period of reference, relayed by pollution from agricultural activities that was by no means negligible (Billen et al., 2007). The picture we have drawn nonetheless shows that urban impact must be put into perspective. If we are to understand the evolution of river systems and interactions between society and nature, we must take into account the role of local history and that of the history of technology - and more generally the environmental history. Reasoning to extremes, we might say that the state of the Seine is by and large the result of the value attached to human urine and excrement, a value that has not always been negative as is the case today. When all is said and done, the interdisciplinary approach and its pertinence with regard to the problems of today are necessary if we are to grasp the issues at stake in urban hygiene as well as those raised by the European Union Water Framework Directive of 2000, which other contributions in this volume refer to.

\section{English Version by RCT.}

Acknowledgements. This study was undertaken as part of the PIREN-Seine research programme (http://www.sisyphe.jussieu.fr/ internet/piren/), which provided the funding for it. I would like to thank G. Billen for his support.

Edited by: A. Ducharne

\section{References}

Annuaire statistique de la ville de Paris, année..., Paris, 18801967.

Arnould, J.: Nouveaux éléments d'hygiène, $2 \mathrm{~d}$ ed., Baillière et fils, Paris, VIII+1403 pp., 1889.

Ayres, R. U. and Simonis, U. E.: Industrial Metabolism: Restructuring for Sustainable Development, United Nations University Press, Tokyo, New York, Paris, 1994.

Barles, S.: L'invention des eaux usées : L'assainissement de Paris, de la fin de l'Ancien Régime à la seconde guerre mondiale, edited by: Bernhardt, C. and Massard-Guilbaud, G., Presses de l'Université Blaise Pascal, Clermont-Ferrand, 129-156, 2002a.

Barles, S. (Ed.): Analyse rétrospective du système Seine- Rapport de synthèse dans le cadre du programme PIREN-Seine 19982001, UMR CNRS 7619 Sisyphe, Paris, 57 pp., http://www. sisyphe.jussieu.fr/internet/piren/, 2002b.

Barles, S.: L'invention des déchets urbains, France, 1790-1970, Champ Vallon, Seyssel, 297 pp., 2005a.

Barles, S.: A metabolic approach to the city: nineteenth and twentieth century Paris, in: Resources of the City: Contributions to an Environmental History of Modern Europe, edited by: Luckin, B., Massard-Guilbaud, G., and Schott, D., Ashgate, Aldershot, 28-47, 2005b. 
Barles, S.: Feeding the city: food consumption and circulation of nitrogen, Paris, 1801-1914, Sci. Total Environ., 375, 48-58, 2007.

Barles, S. and Lestel, L.: The nitrogen question: industrialization, urbanization, and river quality in Paris, 1830-1939, J. Urban Hist., 33, 794-812, 2007.

Baudrillart, H.: Les populations agricoles de la France. Maine, Anjou, Touraine, Poitou, Flandre, Artois, Picardie, Île-de-France, passé et présent, Librairie Guillaumin, Paris, 455-626, 1888.

Beaudemoulin, L. A.: Assainissement de Paris, Revue de l'architecture et des travaux publics, 11, 131-138, 1853.

Bechmann, G.: Salubrité urbaine. Distribution d'eau et assainissement, 2d ed., Baudry, Paris, 665 pp., 1899.

Belgrand, E.: Les travaux souterrains de Paris. Les égouts - les vidanges, Dunod, Paris, 397 pp., 1887.

Billen, G., Garnier, J., Deligne, C., and Billen, C.: Estimates of early-industrial inputs of nutrients to river systems: Implication for coastal eutrophication, Sci. Total Environ., 243-244, 43-52, 1999.

Billen, G., Garnier, J., Némery, J., Sebillo, M., Sferratore, A., Barles, S., Benoit, P., and Benoît, M.: A long-term view of nutrients transfers through the Seine river continuum, Sci. Total Environ., 375, 80-97, 2007.

Bulletin de statistique municipale de la ville de Paris, année 1865, De Mourgues, Paris, 1866.

Cebron de Lisle, P.: L'eau à Paris au XIXe siècle, $\mathrm{PhD}$ thesis, University Paris I, 691 pp., 1991.

Chassin, C. L.: Paris hors les murs, Jouaust et Sigaux, Paris, 223$238,1889$.

Courmont, J., Lesieur, C., and Rochaix, A.: Précis d'hygiène, 4th ed., Masson, Paris, 956 pp., 1932.

Cun, C. and Vilagines, R.: Time Series Analysis on Chlorides, Nitrates, Ammonium and Dissolved Oxygen Concentrations in the Seine River near Paris, Sci. Total Environ., 208, 59-69, 1997.

Darcy, H.: Les fontaines publiques de la ville de Dijon, V. Dalmont, Paris, VII+647 pp., 1856.

Daujat, A.: Deux cents ans d'évolution de la fertilité de la terre de France, Chambres d'agriculture, 115, 1-16, 1957.

de Freycinet, C.: Principes d'assainissement des villes, Dunod, Paris, X+428 pp., 1870 .

Douglas, I., Hodgson, R., and Lawson, N.: Industry, environment and health through 200 years in Manchester, Ecol. Econ., 41, 235-255, 2002.

Dumas, J. B.: Rapport conclusif, in: Enquête sur les engrais industriels, J. Rothschild, Paris, I-XXXI, 1866.

Dureau, G.: Traité de la culture de la betterave à sucre, $2 \mathrm{~d}$ ed., Journal des fabricants de sucre Pub., Paris, IV+554pp., 1886.

Emmery, H. C.: Égouts et bornes-fontaines, Annales des Ponts et Chaussées, 1, 241-288, 1834.

Emmery, H. C.: Statistique des eaux de la ville de Paris, Annales des Ponts et Chaussées, 1, 145-270, 1840.

Feuillade, M.: L'assainissement de la Seine, Travaux, special issue "Direction générale des services techniques de la ville de Paris", 25-36, 1966.

Fierro, A.: Histoire et dictionnaire de Paris, Robert Laffont, Paris, 1580 pp., 1996.

Gastinel, A.: Les égouts de Paris, Étude d'hygiène urbaine, $\mathrm{H}$. Jouve, Paris, 92 pp., 1894.

Gérards, É.: Paris souterrain, Garnier Frères, Paris, II+667 pp., 1907.
Gilbert, H.: La direction technique du port de Paris, Travaux, special issue "Direction générale des services techniques de la ville de Paris", 219-256, 1958.

Girardin, J. and Du Breuil, A.: Traité élémentaire d'agriculture, 4th ed., Garnier frères, Paris, 256-636, 1885.

Goddard, N.: "A mine of wealth"? The Victorians and agricultural value of sewage, J. Hist. Geogr., 22(3), 274-290, 1996.

Guillerme, A.: La naissance de l'industrie à Paris, entre sueurs et vapeurs (1780-1830), Champ Vallon, Seyssel, II+432 pp., 2007.

Hamlin, C.: Sewage: Waste or resource? A historical perspective, Environment, 22(8), 16-20, 38-42, 1980.

Haussmann, G. E.: Mémoires, edited by: Choay, F., Seuil, Paris, 946-1028, 2000.

Jacquemet, G.: Urbanisme parisien, La bataille du tout-à-l'égout à la fin du XIXe siècle, Revue d'histoire moderne et contemporaine, 26, 505-548, 1979.

Kennedy C., Cuddihy, J., and Engel-Yan, J.: The changing metabolism of cities, J. Ind. Ecol., 11, 43-59, 2007.

Koch, P.: Direction technique des eaux et de l'assainissement, Travaux, 180bis, special issue "Direction générale des services techniques de la ville de Paris", 79-156, 1949.

Koch, P.: L'assainissement des agglomérations, L'évacuation de l'effluent urbain, Eyrolles, Paris, 307 pp., 1937.

Labarraque, A. G., Chevallier, A., and Parent-Duchâtelet, A. J. B.: Rapport sur les améliorations à introduire dans les fosses d'aisances, leur mode de vidange, et les voiries de la ville de Paris, Annales d'hygiène publique et de médecine légale, 14, 258-331, 1835.

Lachaise, C.: Topographie médicale de Paris, J. B. Baillière, Paris, 336 pp., 1822.

Lestel, L.: Experts and water quality in Paris in 1870, in: Resources of the City: Contributions to an Environmental History of Modern Europe, edited by: Luckin, B., Massard-Guilbaud, G., and Schott, D., Ashgate, Aldershot, 203-214, 2005.

Loriferne, H. (Ed.): 40 ans de politique de l'eau en France, Economica, Paris, 525 pp., 1987.

Mårald, E.: Everything circulates: agricultural chemistry and recycling theories in the second half of the nineteenth century, Environment and History, 8, 65-84, 2002.

Martin, L.: Encyclopédie municipale de la ville de Paris, NegerReeb, Paris, 781-1239, 1902.

Melosi, M. V.: Cities, technical systems and the environment, Environmental History Review, 14, 45-64, 1990.

Melosi, M. V.: The sanitary city: urban infrastructure in America from colonial times to the present, The Johns Hopkins University Press, Baltimore and London, xii+578 pp., 2000.

Mille, A. A.: Mémoire sur le service des vidanges publiques de la ville de Paris, Annales des ponts et chaussées, 1, 129-157, 1854.

Mille, A. A. and Durand-Claye, A.: Compte-rendu des essais d'utilisation et d'épuration, Régnier et Dourdet, Paris, 117 pp., 1869.

Ministère de la Reconstruction et de l'Urbanisme: Instruction technique relative à l'assainissement des agglomérations, circulaire CG 1333 du 22 févr. 1949, Imprimerie Nationale, Paris, 1949.

Neri Serneri, S.: Water pollution in Italy: the failure of the hygienic approach, 1890s-1960s, in: The Modern Demon, Pollution in Urban and Industrial European Societies, edited by: Bernhardt, C. and Massard-Guilbaud, G., Presses de l'Université Blaise Pascal, Clermont-Ferrand, 157-178, 2002. 
Odum, E. P.: Ecology and Our Endangered Life-Support Systems, Sinauer Associates, Sunderland, MA, 8-25, 1989.

Olivesi, J.: Les services d'assainissement, Travaux, special issue "Direction générale des services techniques de la ville de Paris", 1-3, 1966.

Olivesi, J.: La direction des services industriels et commerciaux de la ville de Paris, Travaux, 455, 5-9, 1973.

Paris et ses réseaux: Naissance d'un mode de vie urbain. XIXe-XXe siècle, Bibliothèque historique de la ville de Paris and Agence culturelle de Paris, Paris, 425pp., 1990.

Parmentier, A. A.: Dissertation sur la nature des eaux de la Seine, avec quelques observations relatives aux propriétés physiques \& économiques de l'eau en général, Buisson, Paris, IV+176 pp., 1787.

Paulet, M.: L'engrais humain, Veuve Comon, Paris, XIX+416 pp., 1853.

Préfecture de la Seine: Assainissement de la Seine. Épuration et utilisation des eaux d'égout, Gauthier-Villars, Paris, 238, 190, 159, 34 pp., 1876.

Rapport fait au préfet de police sur une modification proposée dans le système des égouts de Paris, Annales d'hygiène publique et de médecine légale, 9, 224-226, 1833.

Rapport sur la marche et les effets du choléra-morbus dans Paris et les communes rurales du département de la Seine, Année 1832, Imprimerie Royale, Paris, 1834.

Recherches statistiques sur la ville de Paris et le département de la Seine, Imprimerie Royale, Paris, 1821-1860.
Sentenac, F.: Service technique des eaux et de l'assainissement, Science et Industrie, special issue "Services de la direction générale des travaux de Paris", 47-82, 1928.

Statistique agricole annuelle, 1885, Imprimerie Nationale, Paris, 1886.

Tarr, J. A.: From city to farm: urban wastes and the American farmer, Agr. Hist., 49, 598-612, 1975.

Tarr, J. A.: The metabolism of the industrial city: The case of Pittsburgh, J. Urban Hist., 28(5), 511-545, 2002.

Tarr, J. A. and Ayres, R. U.: The Hudson-Raritan Basin, in: The Earth As Transformed by Human Action, edited by: Turner, B. L. I., Clark, W. C., Kates, R. W., Richards, J. F., Mathews, J. T., and Meyer, W. B., Cambridge University Press with Clark University, Cambridge, 623-639, 1990.

Thouret, M. A.: Rapport sur la voirie de Montfaucon, lu à la Société Royale de Médecine le 11 nov. 1788, Annales d'agriculture Pub., Paris, 40 pp., undated.

Védry, B.: Contribution à l'histoire des procédés d'épuration biologique des eaux résiduaires, Master Thesis, CNAM, 119+59 pp., 1992.

Véron, C.: L'épuration des eaux usées de Paris et de l'agglomération parisienne, Travaux, 44-51, January, 1983.

Vincey, P.: L'assainissement de la Seine et les champs d'épandage de la ville de Paris, P. Renouard, Paris, 143 pp., 1910.

Wolman, A.: The metabolism of cities, Sci. Am., 213, 178-193, 1965. 